\title{
RESEARCH
}

Open Access

\section{Benchmarking the transparency, comprehensiveness and specificity of population nutrition commitments of major food companies in Malaysia}

SeeHoe Ng${ }^{1}$, Gary Sacks², Bridget Kelly ${ }^{1}$, Heather Yeatman ${ }^{1}$, Ella Robinson², Boyd Swinburn ${ }^{2,3}$, Stefanie Vandevijvere ${ }^{3}$, Karuthan Chinna ${ }^{4}$, Mohd Noor Ismail ${ }^{5}$ and Tilakavati Karupaiah ${ }^{6,7^{*}}$

\begin{abstract}
Background: The aim of this study was to assess the commitments of food companies in Malaysia to improving population nutrition using the Business Impact Assessment on population nutrition and obesity (BIA-Obesity) tool and process, and proposing recommendations for industry action in line with government priorities and international norms.

Methods: BIA-Obesity good practice indicators for food industry commitments across a range of domains $(n=6)$ were adapted to the Malaysian context. Euromonitor market share data was used to identify major food and nonalcoholic beverage manufacturers $(n=22)$, quick service restaurants (5), and retailers (6) for inclusion in the assessment. Evidence of commitments, including from national and international entities, were compiled from publicly available information for each company published between 2014 and 2017. Companies were invited to review their gathered evidence and provide further information wherever available. A qualified Expert Panel $(\geq 5$ members for each domain) assessed commitments and disclosures collected against the BIA-Obesity scoring criteria. Weighted scores across domains were added and the derived percentage was used to rank companies. A Review Panel, comprising of the Expert Panel and additional government officials $(n=13)$, then formulated recommendations.

* Correspondence: tilly_karu@yahoo.co.uk

${ }^{6}$ Dietetics Programme, School of Healthcare Sciences, Faculty of Health Sciences, Universiti Kebangsaan Malaysia, 50300 Kuala Lumpur, Malaysia ${ }^{7}$ School of Biosciences, Faculty of Health and Medical Sciences, Taylor's University, 47500 Subang Jaya, Selangor, Malaysia

Full list of author information is available at the end of the article

C C The Author(s). 2020 Open Access This article is licensed under a Creative Commons Attribution 4.0 International License, which permits use, sharing, adaptation, distribution and reproduction in any medium or format, as long as you give appropriate credit to the original author(s) and the source, provide a link to the Creative Commons licence, and indicate if changes were made. The images or other third party material in this article are included in the article's Creative Commons licence, unless indicated otherwise in a credit line to the material. If material is not included in the article's Creative Commons licence and your intended use is not permitted by statutory regulation or exceeds the permitted use, you will need to obtain permission directly from the copyright holder. To view a copy of this licence, visit http://creativecommons.org/licenses/by/4.0/. The Creative Commons Public Domain Dedication waiver (http://creativecommons.org/publicdomain/zero/1.0/) applies to the data made available in this article, unless otherwise stated in a credit line to the data. 
(Continued from previous page)

Results: Of the 33 selected companies, 6 participating companies agreed to provide more information. The median overall BIA-Obesity score was $11 \%$ across food industry sectors with only 8/33 companies achieving a score of > 25\%. Participating $(p<0.001)$ and global $(p=0.036)$ companies achieved significantly higher scores than non-participating, and national or regional companies, respectively. Corporate strategy related to population nutrition (median score of 28\%) was the highest scoring domain, while product formulation, accessibility, and promotion domains scored the lowest (median scores $<10 \%$ ). Recommendations included the establishment of clear targets for product formulation, and strong commitments to reduce the exposure of children to promotion of unhealthy foods.

Conclusions: This is the first BIA-Obesity study to benchmark the population nutrition commitments of major food companies in Asia. Commitments of companies were generally vague and non-specific. In the absence of strong government regulation, an accountability framework, such as provided by the BIA-Obesity, is essential to monitor and benchmark company action to improve population nutrition.

Keywords: Population nutrition, Obesity, Non-communicable diseases, Commitments, Food company, Accountability, Policy

\section{Background}

Malaysia is among the countries with high obesity [1] and non-communicable disease (NCD) [2] rates in the South-East Asian region. The magnitude of risk for premature death from NCDs was $17 \%$ in Malaysia in 2016 [3]. 'Dietary risks' for NCDs in Malaysia account for $14.6 \%$ and 'high body mass index' accounts for 9.9\% of disability-adjusted life years, as estimated by the Global Burden of Disease [4]. Key causes of unhealthy diets are rapid urbanisation, economic growth and social change coupled with trade liberalisation, which collectively trigger food system shifts towards convenience and ultra-processed foods [5-8]. Almost $70 \%$ of Malaysia's population is urbanised [9] with increased market concentration of ultra-processed foods such as sweet and savoury snacks, carbonated drinks, packaged foods, biscuits and confectionery [6]. A recent population study in urban Malaysia highlighted that increased atherogenic and insulinemic risk profiles and obesity were associated with dietary patterns high in calories, fat, and sugars [10].

Prevention of diet-related NCDs requires consideration of the production, marketing, and consumption of commercially produced ultra-processed food products $[11,12]$. The scope for preventive action for improving population nutrition therefore extends to actions by commercial food producers. The WHO [13, 14] recognises the need for transnational, regional and local food and non-alcoholic beverage industries, retailers, and catering companies to take responsibility in tackling obesity and diet-related NCDs via product reformulation, nutrition labelling, responsible marketing to children and healthy food accessibility. The Malaysian government, through its Eleventh Malaysia Plan 20162020 , identified the private sector as a key stakeholder in promoting health, specifically through corporate social responsibility (CSR) activities [15].
Malaysia's National Plan of Action for Nutrition of Malaysia (NPANM) III 2016-2025 [16], and the National Strategic Plan for Non-communicable Disease (NSP-NCD) 2010-2014 [17] and NSP-NCD 2016-2025 [18] set the basis for food industry engagement as part of efforts to improve population nutrition and health. In response to the NSP-NCD, the Federation of Malaysian Manufacturers (FMM) developed a range of related commitments and also engaged more companies to participate in NCDs prevention and control programmes [19]. Industry commitments included self-regulation approaches such as the Responsible Advertising to Children (Malaysia Pledge), and participating in the Malaysian Healthier Choice Logo programme and sugar reformulation initiative [19-21]. In addition, the Malaysian government has stated an intention to implement mandatory regulations such as imposing declarations for total sugars and sodium for all food products, restricting television advertising of foods and beverages high in fat, sugar and salt targeting children, and imposing a sugar tax on unhealthy foods and beverages [16]. Therefore, an independent monitoring framework is needed to generate baseline data to enable future comparisons if there is progress in implementing mandatory regulations.

Monitoring private-sector commitments to population nutrition and health [22] is critical to holding the food industry accountable for their role in efforts to improve population health. This initiative would foster evaluating the extent to which the 'profit-only' model of the food industry is shifting towards a 'health viable profit' model [23], whilst managing conflicts of interest in publicprivate partnerships [14, 24]. The Access to Nutrition Index (ATNI) [25] evaluates food and non-alcoholic beverage manufacturers' commitments at a global level to reducing malnutrition and improving infant nutrition $[25,26]$. A similar tool, the Business Impact Assessment - Obesity (BIA-Obesity) [27] uses less resource intensive 
methods to assess companies' commitments in population nutrition and obesity at the national level. The BIAObesity assessment also includes quick service restaurants (QSR) and retailers such as supermarkets and convenience stores, in addition to food and nonalcoholic beverage manufacturers. The BIA-Obesity tool has previously been applied to Australia [28-30], New Zealand [31], and Canada [32]. It has been recommended that BIA-Obesity country level evaluations be used to monitor and evaluate food industry's progress towards meeting country specific nutrition policies and health criteria, while at the same time building a central database to enable cross-country comparisons [27, 33].

We conducted the first BIA-Obesity in an Asian country. The study included those food companies with national, regional and global presence and with the largest market shares in Malaysia, for each of the four sectors (food and non-alcoholic beverage manufacturing, QSR and retailer sectors). The study also generated recommendations for industry actions, in line with government's priorities and international norms.

\section{Methods}

Business impact assessment on population nutrition and obesity (BIA-obesity)

BIA-Obesity is a defined tool and process developed by the International Network for Food and Obesity/ NCDs Research, Monitoring and Action Support (INFORMAS) $[22,27]$. It utilises a step-based approach to assess the nutrition-related practices of major food companies within a country's food system. Phase I of BIA-Obesity focuses on an assessment of company policies and commitments, while Phase II focuses on company practices, including how commitments translate into actions. This study implemented and reported Phase I of BIA-Obesity in Malaysia.

\section{Adaptation of the tool}

The development of BIA-Obesity has been detailed by Sacks et al. [27]. In brief, the BIA-Obesity assessment incorporates six domains: (1) Corporate strategy - assesses company's overarching approach to addressing obesity and NCDs; (2) Product formulation - assesses targets of nutrients of concern, and portion size or energy reduction in new or existing products; (3) Nutrition labelling - focuses on the display of nutrition information on packaged foods, online and/or menus, where applicable; (4) Promotion practices - benchmarks efforts to reduce marketing of non-core foods that do not fulfil specific nutrition criteria in all settings (including catalogues and in-store promotion in retailer sector), (5) Product accessibility - analyses availability and pricing commitments on healthy products, compared to non-core products; and (6) Relationships with external organisations - evaluates funded and supported corporate social responsibility (CSR) activities. Weighting of the domains used for this assessment was based on several consultations within the INFORMAS network [27]. The allocations are out of 100 as per sectors (see Additional file 1). Scoring was based on the comprehensiveness, transparency and specificity of policies and commitments.

The Malaysian research team adapted the global version of the BIA-Obesity tool for the local context, in conjunction with the INFORMAS private sector module leader (GS). The process of adapting the tool consisted of an iterative process that included multiple face-to-face training workshops on the BIAObesity protocol and discussion amongst the project team. The process for implementation of BIA-Obesity in Malaysia consisted of three stages: compilation of evidence, assessment and review of recommendations, and findings finalisation (Fig. 1).

The BIA-Obesity tool was adapted with several modifications on selected indicators to suit the local context [27]. For instance, BIA-Obesity Malaysia included modifications to assess: (1) voluntary adoption of Malaysian Healthier Choice Logo (product formulation and labelling domains), (2) implementation of quantitative ingredient declarations (QUIDs) (labelling domain); (3) government-endorsed front-of-pack (FOP) labelling scheme (i.e. a single icon for 'energy based on a daily calorie intake of $2000 \mathrm{kcal}$ and Healthier Choice Logo) (labelling domain); (4) specifying policies related to (i) nutrient function claims and (ii) nutrition claim in accordance with permitted claims in Malaysia Food Regulations 1985 (labelling domain) (see Additional file 2).

\section{Stage I: Compilation of Evidence}

\section{a. Selection of companies}

As per the BIA-Obesity protocol [27], the most prominent food companies for each sector (food and nonalcoholic beverages, QSR, and retailers) in Malaysia were selected for assessment based on market share information from the Euromonitor Passport database for 2016 [34-38]. Market share information was based on the retail value (measured based on the Passport database's retail selling price, RSP) for major market sectors but excluding data for unrelated sub-categories (e.g. minimally processed foods such as cooking oils, rice, and mineral waters; and specialty foods like infant formula). The rationale for this exclusion is in tandem with the BIAObesity protocol [27], which aims to identify prominent food companies with the greatest influence on the food environment in Malaysia, giving opportunity to improve population diets. In addition, the tool focused on 


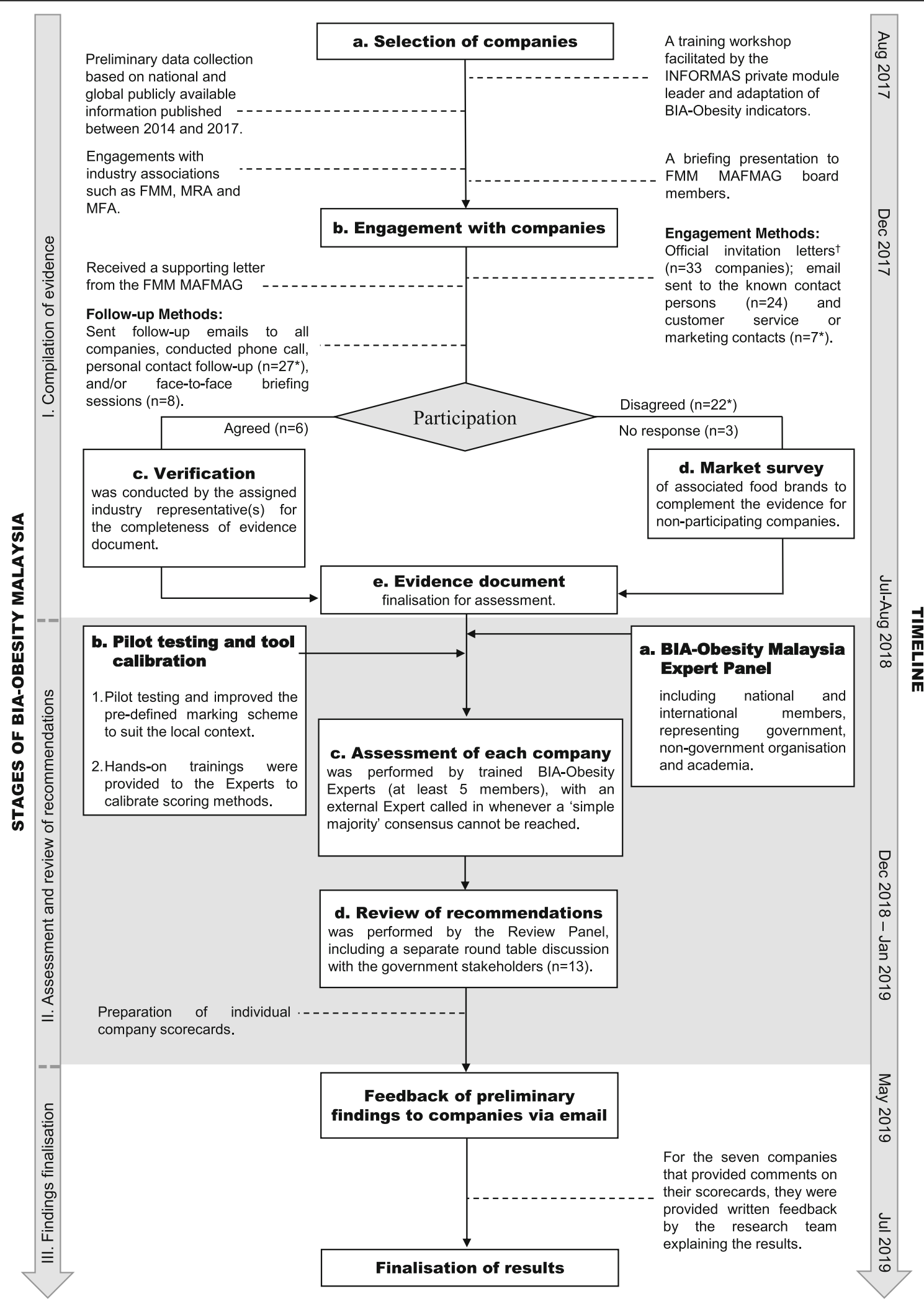

Fig. 1 (See legend on next page.) 
(See figure on previous page.)

Fig. 1 Process of implementation of BIA-Obesity in Malaysia. Abbreviations: BIA-Obesity= Business Impact Assessment-Obesity; FMM = Federation of Malaysian Manufacturers; FMM MAFMAG = Federation of Malaysian Manufacturers Malaysian Food Manufacturing Group; MRA = Malaysia Retailers Association; MFA = Malaysian Franchise Association. Notes: ${ }^{\dagger}$ Invitation letters were posted to all companies except for 3 companies who did not have a maling address. For these companies, communication was via email. *Three companies shared the same parent company and for these the communication was directed to the parent company

initiatives with regards to obesity prevention, which excludes undernutrition issues (e.g. fortified products).

Market share according to food categories (except retailer sector) was applied for company selection (see Additional file 3). The retail values of companies per food category were first ranked from the highest to lowest. Subsequently, company selection was based on two criteria: (1) at least the top quarter of retail values for each subcategory; and (2) sum of the average retail value for all subcategories to fulfil at least $50 \%$ of the relevant market share. The second criterion however was not applied to the retailer sector in Malaysia due to the large number of smaller grocers and the relatively small market share of the largest companies in the sector. Thirtythree food companies were selected, including food and beverage manufacturers $(n=22$, representing $62.9 \%$ of the relevant market share), QSR ( $n=5,79.1 \%$ market share) and retailer $(n=6,26.2 \%$ market share) sectors (Table 1). Most companies selected for inclusion in the study had their parent company located outside of Malaysia (25/33), although six companies were publicly listed in the Malaysian stock market [39].

Company commitments against assessed indicators published between 2014 and 2017 were extracted from publicly available information. Evidence was sourced from company/ brand websites, annual reports, policy statements or guidelines, press releases and social media posts (e.g. Facebook). The study included information published at the national, global industry association and/or parent company level, and government websites. Each company's commitments were then compiled in a Microsoft Word file.

\section{b. Engagement with companies}

Various industry associations were contacted but only FMM was willing to support the project and circulated an endorsement letter to members. Contact information for individual companies was collated from FMM $(n=22)$ and also by accessing company/brand websites, phone call inquiries and/or professional networking websites, such as LinkedIn. The engagement process included sending official invitation letters to companies $(n=33)$; and emails to known contact persons $(n=24)$ and customer service or marketing contacts $(n=7)$ (see Additional file 4). Information related to the research purpose and process, industry's role, risks and benefits, as well as the use of research outcomes were provided to the selected companies. Subsequent follow-up emails, phone calls and/or individual briefing sessions $(n=8)$ were conducted in an effort to increase company participation by providing more information about the study.

\section{c. Verification}

Company-specific evidence in a summarised document was sent to each of the participating company contacts. Participating companies were those that assigned a representative(s) to verify the evidence document, as well as provide additional evidence if available and substantiated. In total, six participating companies went through this process. The verification process took 3 to 5 months. Participating companies returned a verification sign-off form and there was a non-disclosure clause to keep confidential statements disclosed solely for scoring purposes.

\section{d. Market survey}

Non-participating companies were those which did not consent to verify the evidence document. Their assessment was consequently based on publicly available information. This is consistent with other studies [26, $28-30,32,40]$. Market surveys of non-participating companies were conducted on a sample of in-store products of food and beverage manufacturers, menus for QSR and in-house brands for retailer sectors. Photographs of products of these companies were captured to provide supplementary evidence for selected indicators of the nutrition labelling domain. These included availabilities of QUIDs; total sugars, added sugars or trans-fat content on back-of-pack labelling; types of FOP labelling; and/or menu labelling.

\section{e. Evidence document}

With the completion of the data collection process for participating and non-participating companies, the finalised evidence documents were formatted as per indicators for each company to be evaluated. Evidence was consolidated for national and global commitments. 
Table 1 Characteristics of the selected companies $(n=33)$ across sectors

\begin{tabular}{|c|c|c|c|c|c|}
\hline No. & National company name & $\begin{array}{l}\text { Assigned } \\
\text { name }\end{array}$ & $\begin{array}{l}\text { Market } \\
\left.\text { share* }^{*} \%\right)\end{array}$ & $\begin{array}{l}\text { Characteristics } \\
\text { of the company }\end{array}$ & Category/ sub-category* \\
\hline \multicolumn{6}{|c|}{ Manufacturer sector (total market share $=62.9 \%$ ) } \\
\hline 1. & $\begin{array}{l}\text { Fraser \& Neave Holdings } \\
\text { Bhd. }\end{array}$ & $\begin{array}{l}\text { Fraser \& } \\
\text { Neave }\end{array}$ & 11.3 & $\begin{array}{l}\text { Regional } \\
\text { company }\end{array}$ & $\begin{array}{l}\text { Ice-cream, drinking milk products, other dairy, carbonates, concentrates, } \\
\text { juice, RTD Tea, sports and energy drinks, and Asian specialty drinks }\end{array}$ \\
\hline 2. & Nestlé (M) Bhd. & Nestlé & 10.9 & $\begin{array}{l}\text { Global } \\
\text { company }\end{array}$ & $\begin{array}{l}\text { Confectionery, ice-cream, RTE cereal, instant noodles, drinking milk prod } \\
\text { ucts, yoghurt products, other dairy, and RTD coffee }\end{array}$ \\
\hline 3. & Yeo Hiap Seng (M) Bhd. & $\begin{array}{l}\text { Yeo Hiap } \\
\text { Seng }\end{array}$ & 6.0 & $\begin{array}{l}\text { Regional } \\
\text { company }\end{array}$ & $\begin{array}{l}\text { Ready meals, processed meat and seafood, spread, instant noodles, } \\
\text { drinking milk products, juice, and RTD tea, and Asian specialty drinks }\end{array}$ \\
\hline 4. & $\begin{array}{l}\text { Mondelēz (M) Sales } \\
\text { Sdn. Bhd. }\end{array}$ & Mondelēz & 4.0 & $\begin{array}{l}\text { Global } \\
\text { company }\end{array}$ & Biscuits, confectionery, savoury drinks, and cheese \\
\hline 5. & $\begin{array}{l}\text { Etika Group of } \\
\text { Companies }\end{array}$ & Etika Group & 3.7 & $\begin{array}{l}\text { Global } \\
\text { company }\end{array}$ & $\begin{array}{l}\text { Other dairy, carbonates, juice, RTD coffee, RTD tea, and sports and } \\
\text { energy drinks }\end{array}$ \\
\hline 6. & $\begin{array}{l}\text { Campbell Soup SEA Sdn. } \\
\text { Bhd. }\end{array}$ & $\begin{array}{l}\text { Campbell's } \\
\text { Soup }\end{array}$ & 3.4 & $\begin{array}{l}\text { Global } \\
\text { company }\end{array}$ & Biscuits, and soup \\
\hline 7. & Malaysia Milk Sdn. Bhd. & Malaysia Milk & 3.3 & $\begin{array}{l}\text { Regional } \\
\text { company }\end{array}$ & $\begin{array}{l}\text { Drinking milk products, yoghurt products, other dairy, juice, and RTD } \\
\text { tea }\end{array}$ \\
\hline 8. & $\begin{array}{l}\text { Unilever (M) Holdings } \\
\text { Sdn. Bhd. }\end{array}$ & Unilever & 3.2 & $\begin{array}{l}\text { Global } \\
\text { company }\end{array}$ & Ice-cream, ready meals, soup, and spread \\
\hline 9. & Coca-Cola Malaysia & Coca-Cola & 3.1 & $\begin{array}{l}\text { Global } \\
\text { company }\end{array}$ & Carbonates, juice, and RTD tea \\
\hline 10. & $\begin{array}{l}\text { Fonterra Brands (M) } \\
\text { Sdn. Bhd. }\end{array}$ & Fonterra & 2.2 & $\begin{array}{l}\text { Global } \\
\text { company }\end{array}$ & Cheese, drinking milk products, yoghurt products, and other dairy \\
\hline 11. & $\begin{array}{l}\text { Kellogg Asia Marketing } \\
\text { Inc. }\end{array}$ & Kellogg's & 2.2 & $\begin{array}{l}\text { Global } \\
\text { company }\end{array}$ & Savoury snacks and RTE cereal \\
\hline 12. & $\begin{array}{l}\text { Barkath Co-Ro Mfg } \\
\text { Sdn. Bhd. }\end{array}$ & $\begin{array}{l}\text { Barkath } \\
\text { Co-Ro }\end{array}$ & 1.6 & $\begin{array}{l}\text { Global } \\
\text { company }\end{array}$ & Concentrates \\
\hline 13. & $\begin{array}{l}\text { Dutch Lady Milk } \\
\text { Industries Bhd. }\end{array}$ & Dutch Lady & 1.5 & $\begin{array}{l}\text { Global } \\
\text { company }^{\dagger}\end{array}$ & Drinking milk products and yoghurt products \\
\hline 14. & $\begin{array}{l}\text { Mamee-Double Decker } \\
\text { (M) Sdn. Bhd. }\end{array}$ & Mamee & 1.4 & $\begin{array}{l}\text { National } \\
\text { company }\end{array}$ & Savoury snacks, instant noodles, and yoghurt products \\
\hline 15. & $\begin{array}{l}\text { Gardenia Bakery KL } \\
\text { Sdn. Bhd. }\end{array}$ & Gardenia & 1.2 & $\begin{array}{l}\text { Regional } \\
\text { company }\end{array}$ & Baked goods and spread \\
\hline 16. & $\begin{array}{l}\text { Hup Seng Perusahaan } \\
\text { Makanan (M) Sdn. Bhd. }\end{array}$ & Hup Seng & 0.8 & $\begin{array}{l}\text { National } \\
\text { company }^{\dagger}\end{array}$ & Biscuits and savoury snacks \\
\hline 17. & $\begin{array}{l}\text { Munchy Food Industries } \\
\text { Sdn. Bhd. }\end{array}$ & Munchy's & 0.8 & $\begin{array}{l}\text { National } \\
\text { company }\end{array}$ & Biscuits and savoury snacks \\
\hline 18. & Ferrero SpA & Ferrero & 0.6 & $\begin{array}{l}\text { Global } \\
\text { company }\end{array}$ & Confectionery and spread \\
\hline 19. & $\begin{array}{l}\text { Clouet \& Co (KL) Sdn. } \\
\text { Bhd. }\end{array}$ & $\begin{array}{l}\text { Ayam } \\
\text { Brand }\end{array}$ & 0.6 & $\begin{array}{l}\text { Global } \\
\text { company }\end{array}$ & Processed meat and seafood, and juice \\
\hline 20. & $\begin{array}{l}\text { The Italian Baker Sdn. } \\
\text { Bhd. }\end{array}$ & Massimo & 0.6 & $\begin{array}{l}\text { National } \\
\text { company }\end{array}$ & Baked goods \\
\hline 21. & $\begin{array}{l}\text { Ayamas Food Corp } \\
\text { Sdn. Bhd. }\end{array}$ & Ayamas & 0.3 & $\begin{array}{l}\text { National } \\
\text { company }\end{array}$ & Processed meat and seafood \\
\hline 22. & $\begin{array}{l}\text { Ramly Food Processing } \\
\text { Sdn. Bhd. }\end{array}$ & Ramly & 0.3 & $\begin{array}{l}\text { National } \\
\text { company }\end{array}$ & Processed meat and seafood \\
\hline
\end{tabular}

Quick service restaurant sector (total market share $=79.1 \%$ )

\begin{tabular}{|c|c|c|c|c|}
\hline $\begin{array}{l}\text { 23. QSR Stores Sdn. Bhd. } \\
\text { (Pizza Hut) }\end{array}$ & Pizza Hut & 26.3 & $\begin{array}{l}\text { Global } \\
\text { company }\end{array}$ & Pizza consumer foodservice \\
\hline $\begin{array}{l}\text { 24. QSR Stores Sdn. Bhd. } \\
\text { (KFC) }\end{array}$ & $\mathrm{KFC}$ & 21.0 & $\begin{array}{l}\text { Global } \\
\text { company }\end{array}$ & Fast food \\
\hline $\begin{array}{l}\text { Dommal Food Services } \\
\text { Sdn. Bhd. (Domino's) }\end{array}$ & Domino's & 15.8 & $\begin{array}{l}\text { Global } \\
\text { company }\end{array}$ & Pizza consumer foodservi \\
\hline
\end{tabular}


Table 1 Characteristics of the selected companies $(n=33)$ across sectors (Continued)

\begin{tabular}{|c|c|c|c|c|c|}
\hline No. & National company name & $\begin{array}{l}\text { Assigned } \\
\text { name }\end{array}$ & $\begin{array}{l}\text { Market } \\
\text { share* }(\%)\end{array}$ & $\begin{array}{l}\text { Characteristics } \\
\text { of the company }\end{array}$ & Category/ sub-category* \\
\hline 26. & $\begin{array}{l}\text { Gerbang Alaf Restaurants } \\
\text { Sdn. Bhd. (McDonald's) }\end{array}$ & McDonald's & 13.8 & $\begin{array}{l}\text { Global } \\
\text { company }\end{array}$ & Fast food \\
\hline 27. & $\begin{array}{l}\text { Golden Donuts Sdn. Bhd. } \\
\text { (Dunkin' Donuts) }\end{array}$ & $\begin{array}{l}\text { Dunkin' } \\
\text { Donuts }\end{array}$ & 2.4 & $\begin{array}{l}\text { Global } \\
\text { company }\end{array}$ & Fast food \\
\hline \multicolumn{6}{|c|}{ Retailer sector (total market share $=\mathbf{2 6 . 2 \% )}$} \\
\hline 28. & GCH Retail (M) Sdn. Bhd. & Giant & 9.3 & $\begin{array}{l}\text { Global } \\
\text { company }\end{array}$ & Food retailer \\
\hline 29. & $\begin{array}{l}\text { Tesco Stores (M) Sdn. } \\
\text { Bhd. }\end{array}$ & Tesco & 7.0 & $\begin{array}{l}\text { Global } \\
\text { company }\end{array}$ & Food retailer \\
\hline 30. & $\begin{array}{l}\text { 7-Eleven Malaysia Sdn. } \\
\text { Bhd. }\end{array}$ & 7-Eleven & 3.4 & $\begin{array}{l}\text { Global } \\
\text { company }^{+}\end{array}$ & Convenience store chain \\
\hline 31. & AEON Group & $\begin{array}{l}\text { Aeon } \\
\text { Group }\end{array}$ & 2.9 & $\begin{array}{l}\text { Global } \\
\text { company }^{+}\end{array}$ & Food retailer \\
\hline 32. & $\begin{array}{l}\text { Econsave Cash \& } \\
\text { Carry Sdn. Bhd. }\end{array}$ & Econsave & 2.6 & $\begin{array}{l}\text { National } \\
\text { company }\end{array}$ & Food retailer \\
\hline 33. & $\begin{array}{l}\text { Mydin Mohamed } \\
\text { Holdings Bhd. }\end{array}$ & Mydin & 1.0 & $\begin{array}{l}\text { National } \\
\text { company }\end{array}$ & Food retailer \\
\hline
\end{tabular}

Abbreviations: RTD ready-to-drink, RTE ready-to-eat

*Market share was extracted from Euromonitor Passport datasets Year 2016 [34-38] as per the retail selling price values of investigated category/ sub-category ${ }^{\dagger}$ At least one subsidiary publicly listed company in the Malaysian stock market [39]

Notes

1. Definitions of the characteristics of the company

a. A global company is defined as providing goods or service worldwide across regions with its headquarters or parent company located outside Malaysia b. A regional company may be a food and/or beverage business operating within the South-East Asian (SEA) region with its headquarters or parent company located outside Malaysia but within any of the SEA countries

c. A national company is denoted as a company mainly distributing its goods or services within Malaysia and its headquarters or parent company located in Malaysia

2. Etika Group of Companies included Etika Beverages Sdn. Bhd. (manufacturer for soft drinks) and Etika Dairies Sdn. Bhd. (manufacturer of other dairy namely condensed or evaporated milk)

3. AEON Group included AEON Big (M) Sdn. Bhd. and AEON Co. (M) Bhd. (a listed company in the Malaysian stock market)

4. QSR Brands (M) Holdings Bhd. included QSR Stores Sdn. Bhd. (Pizza Hut and KFC) and Ayamas Food Corp Sdn. Bhd

These finalised evidence documents underwent the review process as outlined in Stage II.

\section{Stage II: Assessment and Review of Recommendations}

\section{a. BIA-Obesity Malaysia Expert Panel}

A panel of experts (Expert Panel) was established to perform the assessment of company commitments as per the BIA-Obesity scoring protocol. Selection criteria for experts included area of expertise (e.g. public health, nutrition policy), absence of any self-declared conflict of interest (i.e. no formal collaborations with food and beverage companies) and no involvement in similar studies. The invited Expert Panel represented government, nongovernment organisations (NGO) and academia (local and international).

Eight of ten invited experts consented to join the Expert Panel and one expert with a declared conflict of interest was subsequently rejected. The composition of the Expert Panel $(n=7)$ is described in Table 2A. The members had more than 10 years' experience in their field and were from academia $(n=4)$, government $(n=$ $2)$ and an NGO $(n=1)$. Their combined expertise covered public health nutrition $(n=3)$, national nutrition policy development $(n=4)$, and public affairs management $(n=1)$. Prior to the assessment, each member signed a non-disclosure form and agreed to fulfil all confidentiality obligations.

\section{b. Pilot testing and tool calibration}

As part of the iterative process of adapting the BIAObesity tool to the Malaysian context, pilot testing of the assessment criteria was conducted by two experts. Based on the pilot assessments of one company, the scoring scheme was revised before proceeding with a training session for all Expert Panel members to further calibrate the tool. In this process, the scoring scheme was further revised, for example, to include results of the market survey and to add the Healthier Choice Logo as a criterion for assessment of product healthiness.

\section{c. Assessment of each company}


Table 2 Sociodemographic data of panels as part of BIA-Obesity Malaysia process of assessment

\begin{tabular}{|c|c|c|}
\hline Characteristics & $\begin{array}{l}\frac{A}{\text { Expert Panel }^{b}} \\
\text { (n) }\end{array}$ & $\begin{array}{l}\text { B } \\
\begin{array}{l}\text { Review Panel } \\
\text { (n) }\end{array}\end{array}$ \\
\hline \multicolumn{3}{|l|}{ Age (years) } \\
\hline 20-39 & 1 & 3 \\
\hline $40-59$ & 3 & 10 \\
\hline 60 or above & 3 & - \\
\hline \multicolumn{3}{|l|}{ Gender } \\
\hline Male & 2 & 2 \\
\hline Female & 5 & 11 \\
\hline \multicolumn{3}{|l|}{ Education level } \\
\hline Degree & 2 & 7 \\
\hline Master & 1 & 6 \\
\hline $\mathrm{PhD}$ & 4 & - \\
\hline \multicolumn{3}{|l|}{ Professional Background } \\
\hline Academia/ professionals & 4 & - \\
\hline Non-government/ non-profit organisation & 1 & - \\
\hline Government stakeholder & 2 & 13 \\
\hline \multicolumn{3}{|l|}{ Working Experience (years) } \\
\hline $5-10$ & - & 3 \\
\hline $11-20$ & 4 & 7 \\
\hline $21-30$ & 1 & 3 \\
\hline 31 or above & 2 & - \\
\hline \multicolumn{3}{|l|}{ Expertise $^{a}$} \\
\hline Public affairs management (e.g. corporate, inter-agency collaboration including private sector) & 1 & 2 \\
\hline $\begin{array}{l}\text { Public health nutrition (e.g. nutrition promotion, food marketing, food labelling, food education } \\
\text { programme evaluation) }\end{array}$ & 3 & 7 \\
\hline $\begin{array}{l}\text { National policy development (e.g. national nutrition plan, national food and nutrition policy, food } \\
\text { regulations, obesity and/or NCDs prevention) }\end{array}$ & 4 & 5 \\
\hline Food regulations and/or food safety auditing & - & 3 \\
\hline
\end{tabular}

Abbreviations: NCDs non-communicable diseases, PhD Doctor of Philosophy

Notes:

${ }^{a}$ More than one field of expertise may be stated by the Expert or Review Panel.

${ }^{b}$ Seven members of the Expert Panel (including an academic who refereed whenever the 'simple majority rule' failed) performed the assessment.

'The Review Panel comprised the Expert Panel and thirteen government stakeholders who formulated the recommendations. This column only presents the profile of the thirteen government stakeholders involved in the round table session

Within a 4-month period, a minimum of five members of the Expert Panel completed scoring of all companies using the BIA-Obesity Malaysia tool. Communications via emails and video conferencing maximised discussion between the researchers and Expert Panel. Each member scored the evidence independently. Upon consolidating the Expert Panel scores, outliers (i.e. weighted overall score $>1.5$ times of the interquartile range) were returned to relevant expert(s) for re-consideration.

The final score for each indicator was determined based on a 'simple majority rule' such as at least 4 out of
6 members in the Expert Panel casting the same score. In the event that a 'simple majority rule' could not be reached (e.g. where the same number of experts allocated scores to two different values), an additional academic referee was called in to make the final decision. Baharad et al. [41] indicated that 'simple majority rule' was common to organisations in making decisions and adding another voter would be preferred to removing an existing competent voter to reach consensus. Table 3 shows examples of publicly available commitments using illustrative quotes, scoring criteria, and their corresponding scorings, by domain. 


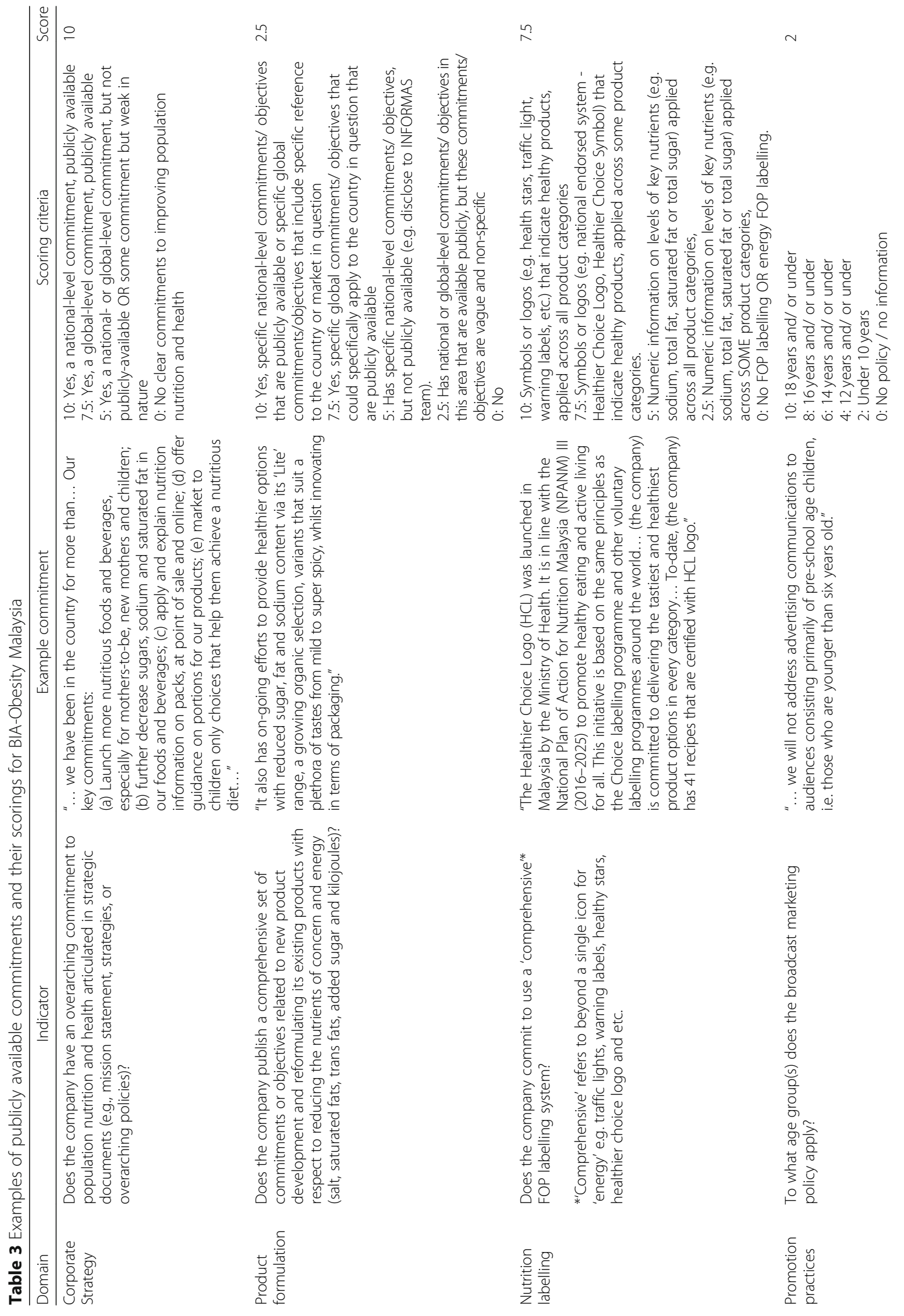


$\mathrm{Ng}$ et al. Globalization and Health

(2020) 16:35

Page 10 of 19

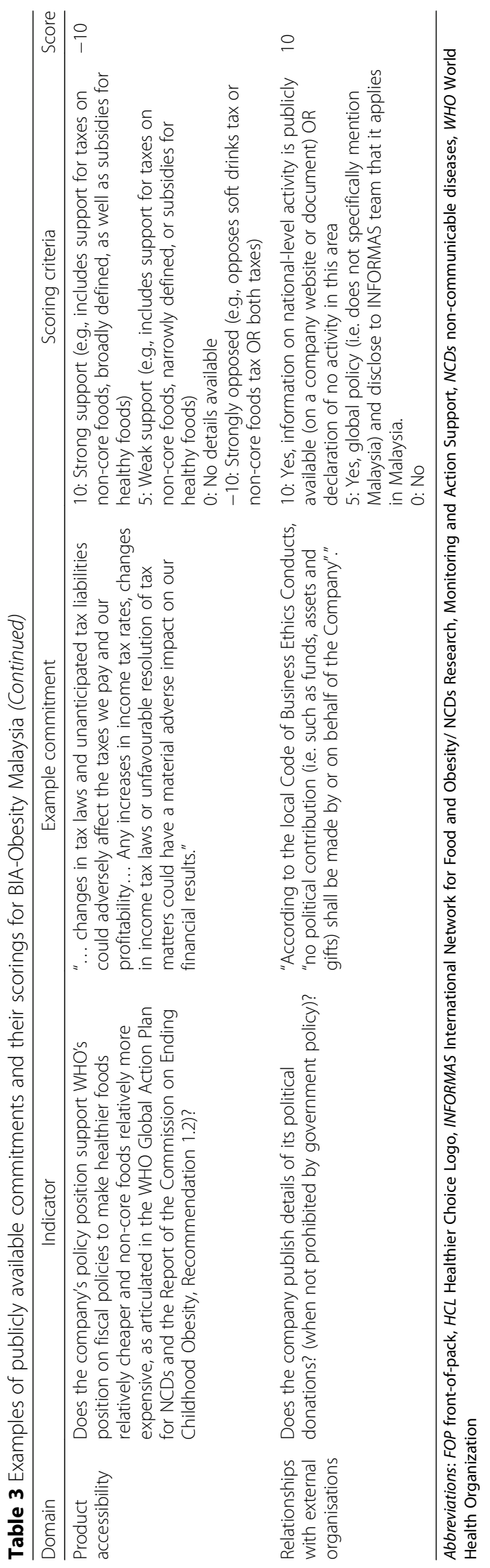




\section{d. Review of recommendations}

The research team developed preliminary recommendations for each company based on Expert Panel assessment of their policies. A Review Panel was established to review and harmonise these recommendations to ensure that these were consistent with national policies, government directions and international standards, as well as achievable under the local conditions. The Review Panel included the Expert Panel members, with additional government stakeholders. Selection criteria for these government stakeholders included regular engagement with food industry on policy implementation matters related to food reformulation, labelling, promotion and/or accessibility, absence of any self-declared conflict of interest, and consenting to attend a discussion.

Hence, in addition to the Expert Panel members, 13 government stakeholders were included on the Review Panel tasked with reviewing the recommendations. Of note, government stakeholders all had a minimum 5 years of working experience with combined expertise of inter-agency collaboration with the private sector $(n=$ $2)$, food regulation and/or food safety auditing $(n=3)$, nutrition policy planning specific to obesity and/or NCD prevention $(n=5)$, and/or public health nutrition $(n=7)$ (Table 2B).

\section{Stage III: Findings Finalisation}

Preliminary scorecards were disseminated to the companies for verification, within a two-week period (see Additional file 5). Comments received from companies were addressed by minor amendments to stated key strengths and company-specific recommendations. All companies were invited to attend a closed-door meeting, held a month later, where overall findings of BIAObesity Malaysia were presented. Fifteen companies attended the meeting. The full technical report was publicly disseminated at a later date.

\section{Data analysis}

Intraclass correlation coefficient (ICC) of the Expert Panel were determined using two-way random model and absolute agreement type across all the indicators as per company assessed. Agreement test of assessed indicators reaching 'simple majority rule' was calculated. Kruskal Wallis testing further examined the weighted score differences between the Expert Panel members, by domains and overall weighted scores. Differences in overall weighted scores were compared between participating and non-participating companies, and according to characteristics of companies (e.g. global vs regional and national companies, and listed vs non-listed companies in the Malaysian stock market [39]) using Mann-Whitney tests. For this study's purpose, a global company is defined as one that provides goods or service worldwide across regions with its headquarters or parent company located outside Malaysia. Whereas, a regional company may be a food and/or beverage business operating within the South-East Asian (SEA) region with its headquarters or parent company located outside Malaysia but within any of the SEA countries. In contrast, a national company is denoted as a company mainly distributing its goods or services within Malaysia and its headquarters or parent company located in Malaysia. Finally, the association of market shares and overall weighted scores were tested using Spearman rank coefficient. IBM SPSS version 21.0 (SPSS Statistics Inc., Chicago IL, USA) was used to perform these analyses, with $p<0.05$ set as the threshold for statistical significance.

\section{Results}

Six out of 33 companies agreed to participate in the BIA-Obesity assessment process. Twenty-four companies declined to participate, while three did not respond. Some declined companies provided reasons for nonparticipation such as resource limitations $(n=2)$, lack of priority as perceived by senior management $(n=3)$, lack of local staff with relevant skills (e.g. nutritionist) to help with evidence collection $(n=2)$, tight schedules $(n=3)$, restriction in the company policy for public disclosure $(n=1)$, and scepticism regarding the assessment $(n=2)$.

\section{Consistency between Expert Panel Scorings}

In terms of consensus between the Expert Panel members, the ICC for 33 companies ranged from 0.83 $(95 \%$ CI $0.75,0.89)$ to $0.99(95 \%$ CI $0.98,0.99)$. The agreement test of assessed indicators reaching 'simple majority rule' was $94.2 \%$ (i.e. 1787 out of 1897 applicable indicators assessed). There was no significant difference in weighted scores by domain between the Expert Panel for all assessed companies $(p>0.05)$.

\section{Overall weighted score}

The overall weighted score for companies varied from $1 \%$ (Ramly) to 60\% (Nestlé) (Fig. 2a). The overall median score was $11 \%$ across food industry sectors, but individual sector comparisons indicated that the median score for food and beverage manufacturers (14\%) was greater than that of QSR and retailer sectors (both recorded as 6\%).

Market share of companies was not significantly associated with the overall weighted scores $(r=0.20, p=$ 0.266 ). Neither was the overall weighted score difference between listed and non-listed companies in the Malaysian stock market $(25.5 \%$ vs $10.3 \% ; U=57.0 ; p=0.263)$. 


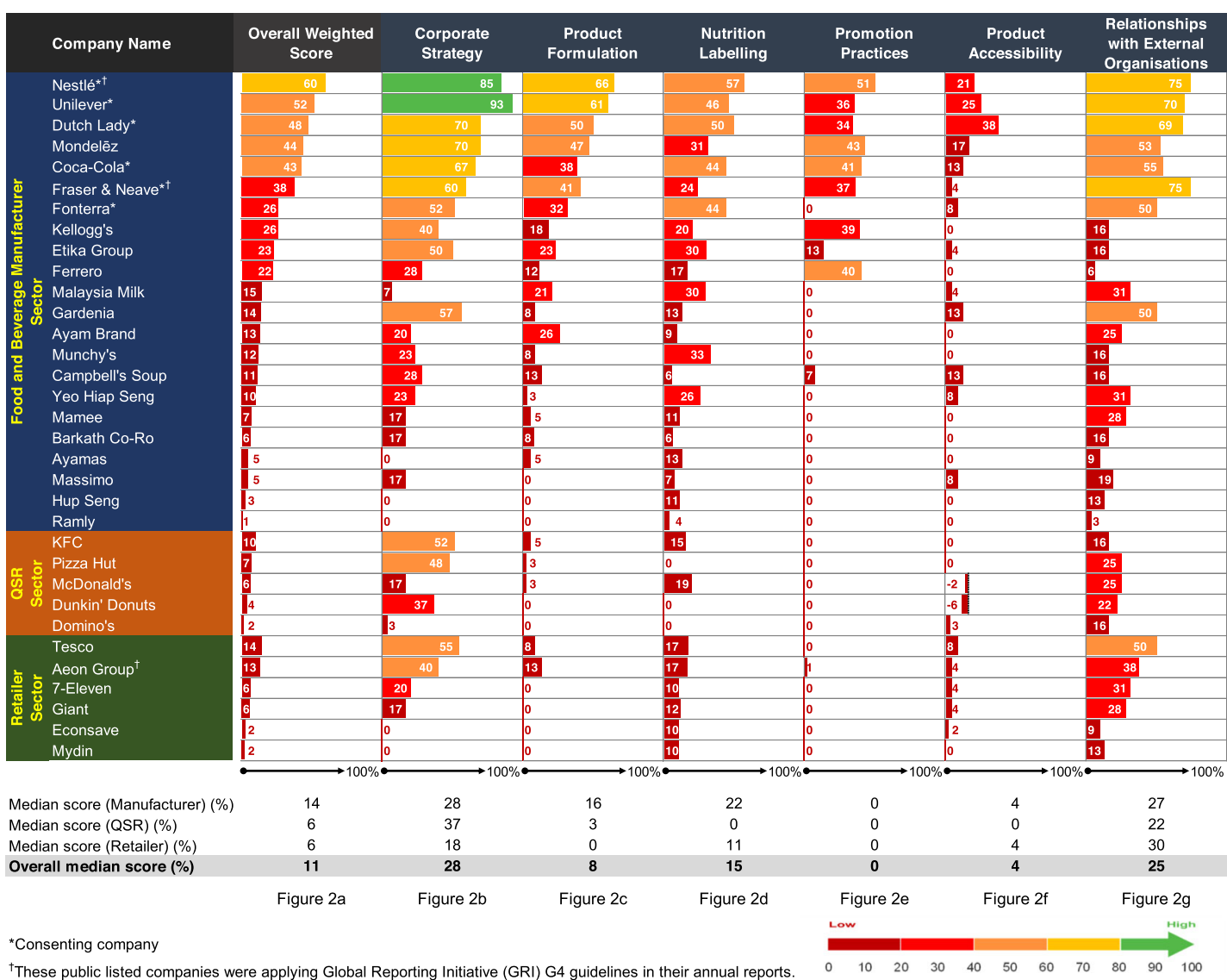

Fig. 2 Overall weighted score (a) and percent of the total number of points by domain (b-g). Notes: 1. The negative scorings in $\mathbf{f}$ were deficit points after taking into consideration of the substantial evidence that the assessed company strongly opposed unhealthy food tax. This was assessed under the indicator - "Does the company's policy position on fiscal policies to make healthier foods relatively more expensive, as articulated in the WHO Global Action Plan for NCDs and the Report of the Commission on Ending Childhood Obesity, Recommendations 1.2". 2. The Expert Panel considered two non-participating companies (Etika Group and McDonald's) showing no explicit evidence published between 2014 and 2017 for the implementation of the Malaysia Pledge. The cited comments were low transparency in reporting, no publicly available individual action plans and nutritional standards, and dynamic change in business ownership or licensees' obligations

The median score of participating companies was significantly higher compared with non-participating companies $(45.1 \%$ vs $6.9 \% ; U=3.0 ; p<0.001)$. Global companies scored significantly higher, compared with regional and national companies ( $13.0 \%$ vs $5.8 \%$; $U=70.0 ; p=0.036$ ).

The following sections describe domain-specific scorings expressed as percent of the total number of points, and the recommendations across sectors. As some indicators were not applicable for some industry companies (e.g. setting a trans-fat target was not applicable to beverage companies), the number of eligible companies varied per indicator.

The recommendations were developed based on collated constructive opinions of the Review Panel, which were generated from discussions on scorings for indicators and consideration of other research (e.g. BIA-Obesity Australia and New Zealand), WHO recommendations, and/or national nutrition plans. The Review Panel also considered differences between food companies global versus local commitments and disclosures (where relevant). Feasibility of recommendations in the Malaysian context, national norms and industry capability were also important considerations during the development of recommendations.

\section{Corporate strategy}

The overall median score (28\%) was highest for the corporate strategy domain with scores ranging between 0 and $93 \%$ (Fig. 2b). Twenty-eight out of 33 companies had policies or statements that included population nutrition and health as part of their business strategy. Companies with higher scores for this domain published their commitments aligning with international agendas (e.g. 2030 Agenda for SDGs, World Health Organizations (WHO) recommendations) and/or national government policies (e.g. NPANM III 2016-2025 or supported Healthier Choice Logo programme). However, most $(22 / 33)$ scored $<50 \%$ and this lower score was 
attributed to weak commitments that were non-specific to the Malaysian context, coupled with irregular reporting.

Key recommendations were to (1) refer national and international recommendations (e.g. NPANM III 20162025, WHO Global NCD Action Plan, SDGs, etc.) when formulating targets and plans; (2) link targets to Key Performance Indicators of senior managers; and (3) report the progress at national level and on a regular basis. Whenever possible, the Review Panel encouraged companies to employ nutritionists, dietitians or equivalent professionals in their business. They also observed the low levels of engagement with the QSR sector with respect to implementation of nutrition policies in the past. Accordingly, the Review Panel called for greater engagement from food companies in regards to implementation of government-led initiatives for improving population nutrition and health.

\section{Product formulation}

The overall median score for the product formulation domain was $8 \%$, with individual scores ranging between 0 and 66\% (Fig. 2c). Many companies (24/33) committed to reformulation to some extent for at least one nutrient of concern such as sodium (8/26 eligible companies), trans-fat (10/30), saturated fat (6/31), added sugars (13/ $33)$, or to reduce the energy content or portion size of their products (10/33). Twelve companies were participating in national and/or global industry initiatives on reformulation (e.g. Healthier Choice Logo programme or other healthy eating initiatives), whereas no such initiatives were observed in the QSR and retailer sectors. Commitments to product formulation included a lack of nutrient reduction targets, application to only select key products and non-specificity to the Malaysian market. In addition, a company's self-determination on 'healthier' food product composition without external verification affected scores.

Recommendations included to (1) set SMART (specific, measurable, achievable, relevant, and time-bound) national targets for product formulation and regularly report on them; (2) align the targets with Healthier Choice Logo and also consider the WHO nutrient profiling systems for all relevant categories. These recommendations were also applicable to the suppliers or third-party manufacturers supplying products to the retailers.

\section{Nutrition labelling}

The overall median score for the nutrition labelling domain was $15 \%$ with the highest score recorded as $57 \%$ (Fig. 2d). Most of the companies (30/33) disclosed commitments related to nutrition labelling with some companies scoring highest for publishing nutrition information online (16/33) and displaying energy on FOP labelling (17/28). Approximately half of the companies included total/ added sugars (13/28) or trans-fat (13/24) content and used Healthier Choice Logo or their own FOP formats $(14 / 28)$ such as numeric information of key nutrients. Less than half of the companies committed to the Malaysian Food Composition Database programme (9/33), disclosed some commitments on using nutrition or health claims only for 'healthy' products $(5 / 28)$ or displayed QUIDs labelling (4/28) for their products. Within the QSR sector, nutrition information on request, such as pamphlets on trays or wall charts, was provided by some companies $(2 / 5)$ but none displayed nutrition information on the menu board. Four retailers participated in a government BeSS (Clean, Safe and Healthy) accreditation for food premises, which has a criterion for minimal calorie tagging on menu.

Key recommendations were to (1) provide comprehensive nutrition labelling online and on pack (e.g. sodium, trans-fat, sugars) and QUIDs; (2) participate in government-led initiatives such as Malaysian Food Composition Database and FOP labelling programmes; and (3) commit that only 'healthier' products (Healthier Choice Logo and/or WHO criteria) are permitted to carry nutrition claims. For QSR and retailer sectors, nutrition information was recommended to be displayed using the same size fonts as for the price tags on the menu board for all takeaways or ready-to-eat foods prepared on site.

\section{Promotion practices}

The overall median score was zero, with only one-third of companies (11/33) having published some commitments to restrict unhealthy food marketing (Fig. 2e). The limited commitments were to restrict promotion in broadcast and non-broadcast media (10/33), primary schools $(9 / 27)$ and secondary schools (2/27), limit the usage of celebrity endorsements (7/33), fantasy and animation characters (6/33) and premium offers (5/33), and to undertake policy compliance audits (6/33). Most of the companies with commitments in this area were signatories to the Malaysia Pledge and/or other global marketing pledges or policies.

Key recommendations included to (1) establish responsible marketing policies for all media and children's settings with strict criteria applied to children up to 18 years old, implement time-based restrictions on children's programming hours, set cut-off at $15-25 \%$ or more of children audience viewership, and apply the WHO nutrient profiling systems, and (2) regularly disclose independent national audits of compliance. Retailers were encouraged to promote 'healthier' products, in line with WHO criteria, on catalogues, in-store promotion and other activities, and the QSR sector were encouraged to refrain from all forms of advertising in 
schools including the provision of branded certificates and vouchers.

\section{Product accessibility}

Most companies (21/33) disclosed some commitments on food accessibility but the overall median score was $4 \%$ (Fig. 2f). Companies reported commitments to increase availability of some 'healthier' products $(15 / 28)$ and their availability at specific settings (3/28), and general commitments to improve product affordability (10/ 33). Three companies provided negative statements on taxation as a means to curb intake of unhealthy food products. Lower scores related to the use of "gimmicks through promotional campaigns" (e.g. Buy 1 Free 1) that aimed to drive sales rather than addressing product accessibility, were observed in this study. The QSR sector provided little evidence that they were committed to healthier product accessibility. In some cases, these companies offered mineral water as a value deal or provided 'healthier' options on request such as sweetcorn and/or mineral water, with the latter provision incurring additional charges for children's combination meals.

Recommendations covered the introduction of policies to (1) apply affordable and sustainable pricing (i.e. not short-term 'price off' marketing practices) for healthier products compared to non-core products, (2) increase availability through placement strategies of 'healthier' products defined by the WHO nutrient profiling systems $[42,43]$, and (3) support the WHO's position on fiscal policies $[13,14]$. The QSR sector was recommended to (1) introduce 'healthier' choices in children and adult combination meals, such as a free water by default or the provision of mineral water, fresh fruits, and vegetable options at no extra charges, and (2) commit to not opening new stores within $500 \mathrm{~m}$ of schools.

\section{Relationships with external organisations}

All companies reported at least one type of relationship with external organisations (Fig. 2g) with scores for this domain ranging between 3 and 75\%. The CSR activities included funding or in-kind support provided to research (6/30), professional organisations (12/31), nutrition education (12/31) and active lifestyle programmes (20/33), public-private partnerships (15/33), and philanthropic activities (29/33). Some companies explicitly disclosed their position to restrict political donations (9/ 33). No company made a specific commitment to conduct CSR activities independent of brand, logo or company promotions.

Evidence revealed that companies often reported relationships with external organisations in a nonconsolidated manner and/or not specific to the Malaysian market. Therefore, key recommendations included to (1) publicly disclose all national CSR activities in a regular and consolidated manner, and (2) avoid commercial branding and product promotion in their nutrition and healthy lifestyle programmes.

\section{Discussion}

This was the first BIA-Obesity study to assess the nutrition commitments and disclosure practices of major food companies in Asia. In terms of overall scorings for the 33 companies, less than a quarter scored more than $25 \%$ (overall median score $=11.0 \%$ ). Commitments and disclosures of companies in Malaysia were evaluated across six domains of the BIA-Obesity, providing overall median scores for domains ranging between 0 and $28 \%$. Companies performed the worst for commitments related to product formulation, product accessibility, and promotion practices domains (all $<10 \%)$. Commitments were often non-specific to the Malaysian market and vague. Across the domains, lower scores were noted related to self-determination of 'healthy' products without external verification (e.g. the products that were deemed sufficiently 'healthy' to be marketed to children).

The weak nature of food company commitments and disclosures, as discussed above, has also been encountered in other studies. For instance, Cetthakrikul et al. [44] reported food companies in Thailand lacked sufficient specificity and often did not provide detailed criteria in food marketing to children, nutrition and health claims, and food accessibility. A review of commitments and disclosures of companies in 30 countries [33] also revealed wide variations in country specific policies of transnational chain restaurants regarding improving healthfulness of their menus, as well as time commitments to executing these targets. Lack of disclosures and uncertain application of global commitments within Malaysia were identified as issues for most of the global and regional companies. As explained by the ATNF [26], nutrition activities of such companies as reported in their global reports mainly applied to major markets, which might exclude smaller countries such as Malaysia.

The findings from this assessment performed for Malaysia highlights differences in commitments and disclosure practices of companies between high-income countries and low- and middle-income countries (LMICs). As the assessment criteria of BIA-Obesity were modified to suit the Malaysian context, direct countrycomparisons could not be reliably made across the board. However, general patterns could still be observed, revealing lower median scores for Malaysia, compared to Australia [28-30], New Zealand [31], and Canada [32]. Moreover, companies that were assessed in both Malaysia and Australia/ New Zealand, typically scored lower in Malaysia. In contrast, companies with market presence in both Malaysia and Canada [32] elicited 
similar scores in both countries. Sacks et al. [45] suggested that variation of policies within a company for different markets may reflect the different country contexts, including different regulatory pressures, and different consumer demand patterns, but the particular drivers of these variations warrant further exploration.

The Global Reporting Initiative (GRI) Standards serve as a guide to companies to practise sustainability reporting to align their corporate position in relation to SDG target 12.6. Publicly listed companies in the Malaysian stock market were more likely than non-listed companies to fulfil GRI as detected by this study, and most of these companies were in line with Malaysia's NPANM III 2016-2025, the global WHO's recommendations and/or SDGs. These companies also were participating in Malaysian government-led initiatives such as Healthier Choice Logo, BeSS (Clean, Safe and Healthy), and/or Malaysian Food Composition Database programmes. Additionally, two out of three companies were signatories to the Malaysia Pledge, practised an internal marketing policy with compliance audits, and published CSR activities including a policy to restrict political donations. Such activities complement some indicators included in the Sustainability Reporting Guide (SRG) recommended by the Bursa Malaysia [46], which is adapted from GRI. Thus, sustainability reporting would likely encourage the inclusion of population nutrition and health strategies into the business model as evidenced by GRI or SRG compliant companies. This study highlights the need for the government to consider regulatory changes to integrate recommendations for areas evaluated by BIA-Obesity Malaysia. This could lead to a nationally endorsed sustainability reporting system related to population nutrition for food and non-alcoholic beverage companies. Furthermore, formulating appropriate fiscal policies (e.g. taxation rebates or incentives) would encourage sustainability reporting and increase transparency in businesses.

Transparency is a key element of accountability [47]. This element was central to recommendations made across most BIA-Obesity domains, which emphasised the importance of public disclosures of company commitments and/or regular reporting for population nutrition and health. Participating companies in our study who provided more evidence for the BIA-Obesity assessment were also more likely to make public their policy information and this concurred with findings from similar studies in New Zealand, Australia, and Canada [28, 31, 32]. These may indicate preparedness for evidence compilation and global company policies tuned towards population nutrition and health. They also may have a greater tendency to publicise related commitments because of global pressure for public-private partnerships to tackle obesity and NCDs prevention [44].
The observed low levels of commitment from companies towards population nutrition puts into question the effectiveness of food industry self-regulation in this area. Moreover, we note that a preference for voluntary industry initiatives in the area of nutrition have been identified as a key strategy used by the food industry as part of efforts to influence public policy in their favour [48]. This 'policy substitution' strategy is often coupled with other corporate political activities, such as direct lobbying of government and constituency building activities (including public-private partnerships), to weaken or delay public policy responses [49-51]. In light of well-documented corporate political activities, governments are being urged to implement clear, transparent, and robust guidelines on conflicts of interest and processes to mitigate industry influence on public policy development [23]. Conflict of interest management processes need not completely exclude engagement with industry, particularly as part of policy implementation, but the risks associated with such engagement need to be closely managed. In addition, there is a need for government-led monitoring and evaluation to determine the effectiveness of industry self-regulation on food environment policies.

Varying approaches to nutrition labelling by companies, particularly FOP labelling, were observed in this study. Draper et al. [52] warned that multiple FOP labelling formats in a market would likely limit consumer understanding and lower usage. Relatedly, public health advocates have proposed the application of consistent FOP labelling on all products to improve consumer food choices [53]. Specific to the Healthier Choice Logo programme in Malaysia, its use was viewed as conflicting with stronger FOP labelling implementation [54]. A case in point at the time of this study is the Healthier Choice Logo criteria were limited to selected foods within categories [55] such as cereals which excluded bread but included instant noodles [55] which is viewed as an ultra-processed food [56].

Few sampled companies in this study had committed to the self-regulatory Malaysia Pledge restricting food marketing targeting children. Some concerns regarding the likely population health benefits of the Malaysia Pledge were raised at a WHO bi-regional forum [57], pointing to the lack of reliable systems in place to monitor progress, the small number of signatories, and lack of robust nutrition criteria underpinning the pledge. Most of the assessed companies favoured setting age below 12 years as a cut-off to control unhealthy food promotion to children, whereas the United Nations Committee on the Rights of the Child [58] recommended 18 years old as the target cut-off. All these implied the need to strengthen regulation of unhealthy food marketing following strict criteria as per the 
recommendation of the Review Panel, which was also echoed in an earlier study that called for stronger government-led actions in Malaysia [59].

In the area of product accessibility, a key recommendation from this study emphasised a need for pricing practices that would make healthier products more affordable to the bottom and middle income household groups in Malaysia through sustained lower prices, with less focus on temporary price promotions. A need was also identified for the food retail and manufacturer sectors to improve the placement of healthier products to facilitate easier identification by consumers. The proposed tax incentives for healthier foods as recommended in the NPANM III 2016-2025 [16] may provide incentives for the food industry to shift to the "health viable profit' model, as mooted by Swinburn et al. [23].

In the context of CSR activities, strong branding or product promotion was observed in Malaysia. Since 2007, CSR has been mandatory for companies listed on the Malaysian stock market, with tax incentives for implementation. However, opinion is that most businesses favoured CSR activities linked to philanthropy, rather than population health [46]. Besides, we found little evidence on the effectiveness of reported CSR targeting population health. Kraak et al. [50] indicated that the major challenge in public-private partnerships is to manage conflicts of interest and only allow healthier products for brand-use activities. Therefore, a stricter recommendation was proposed for healthy lifestyle and nutrition programmes to be free from companies' products and/or brands.

The BIA-Obesity tool assessed the strength of profiling systems used by companies for the purposes of food formulation, labelling, marketing to children, and accessibility. In this study, WHO nutrient profiling systems $[42,43]$ were used as the benchmarks for assessing the healthiness of relevant product portfolios of companies. Recommendations generated by the Review Panel for relevant domains also referred to these profiling systems. The WHO systems enable a country model to consider the regulation of taxation, labelling, and guidelines for healthy food provision in public food service settings [14]. Adoption of the WHO systems would ensure a consistent approach to determining nutrient limits for the classification of a 'healthy' product across a range of policy domains $[26,60,61]$. For food companies in Malaysia, it will be important to align relevant policies with 'reputable' nutrient profiling systems, rather than generating custom-fit profiling to suit an individual company's product range.

Through the BIA-Obesity Malaysia process, civil society provided critical assessment and valuable recommendations that focussed on public interests without commercial influence. This academic-led assessment of companies provides strong evidence to the government on the lack of progress in relation to existing selfregulatory policy approaches, which should provide some impetus to shift towards mandatory policies. For the food industry, this study provides evidence of the limitations of existing commitments and disclosure practices to improve related to population nutrition and disclosure practices. A first step for companies would be to formulate SMART commitments and to improve public disclosure of such commitments. The results of this study can also be used by civil society advocates to increase uptake of the study's recommendations.

This study had several methodological strengths. The tool used has been adapted from INFORMAS, which was earlier implemented in Australia [28-30], New Zealand [31], and Canada [32]. The development process was independent from the food and beverage industry [27]. The tool was modified to suit the local context by taking account of local nutrition policies in the assessment criteria to better reflect a country-specific assessment. The innovation of the process included the appointment of the Expert and Review Panels with balanced representation from the government, NGO and academic backgrounds. A positive characteristic of this study was the test agreement adopting the 'simple majority rule' approach which recorded $94.2 \%$ agreement between the Expert Panel members. Dissemination of preliminary individual scorecards to companies and holding a closed-door meeting with industry prior to public release of the findings also ensured that the conduct of the study through to the final stages, remained transparent and unbiased.

However, this study had a number of important limitations. Firstly, this study only conducted Phase I of the BIA-Obesity methods, which assessed commitments and disclosures of food companies in relation to population nutrition and health. Although some corporate political activities like corporate philanthropy were assessed to some extent in this study, other practices identified by Mialon et al. [48] such as political lobbying, funding of research and political donations warrant further investigation. A critical evaluation of the healthiness of companies' product portfolios and the extent of their marketing practices is also recommended as a follow up study. Secondly, the low level of participation by food companies $(n=6 / 33)$ limited the extent of data collection which led to dependence on only publicly available information for non-participating companies. To overcome issues associated with low participation rates, market surveys were conducted to validate evidence and increase credibility of information presented for assessment. The level of participation from companies likely reflected these companies' first-time experience with the BIA-Obesity assessment and it is anticipated that future 
follow-up assessments may overcome this reservation to engage, as has been the experience of similar initiatives elsewhere $[25,26]$. If more food companies participated in the BIA-Obesity process, even with the option of providing information on a confidential basis, this is likely to improve the completeness of the evidence, instead of heavily relying on publicly available information. Moreover, future periodic monitoring via BIA-Obesity may improve food company disclosure practices and thus the accuracy of publicly available information used in the assessment.

\section{Conclusion and policy implications}

This study provided an understanding and critical assessment of the Malaysian food industry's current commitments to improving population nutrition, along with recommendations for change. The lack of efficacious self-regulation in food reformulation, labelling, and marketing, brand-associated CSR activities, and the lack of a uniform credible nutrition profiling system implies that policy makers need to adopt mandatory regulations as part of efforts to create healthier food environments. Appropriate regulatory changes by the government with non-compliance consequences would foster greater adherence of the food industry to policies prioritising population nutrition and health. Furthermore, this study highlighted the need for greater transparency in food company reporting to strengthen accountability for improving population nutrition.

\section{Supplementary information}

Supplementary information accompanies this paper at https://doi.org/10 1186/s12992-020-00560-9.

Additional file 1 : Table S1. Domain Weightings by Sector. Weightings assigned for each domain according to manufacturer, quick service restaurant and retailer sectors.

Additional file $\mathbf{2}$ : Table S2. Indicators for BIA - Obesity Malaysia by Sector. Indicators adapted for BIA-Obesity Malaysia for each domain according to manufacturer, quick service restaurant and retailer sectors.

Additional file $\mathbf{3}$ : Table S3. Market Share of Companies by Food Category. Market share of selected companies by food category according to manufacturer, quick service restaurant and retailer sectors.

Additional file 4. Email Template for Industry Engagement. A sample of the email for industry engagement.

Additional file 5 : Table S4. Example of an Individual Scorecard. A preliminary scorecard [Ayamas Food Corporation Sdn. Bhd. - a selected company] used in 'Stage III: Findings finalisation - Feedback of preliminary findings to companies via email'..

\section{Acknowledgements}

The Economic Planning Unit, Prime Minister's Department for providing country clearance to conduct this research. The Federation of Malaysian Manufacturer provided the access to industry stakeholders.

\section{Authors' contributions}

Author names: SeeHoe Ng (SHN), Gary Sacks (GS), Bridget Kelly (BK), Heather Yeatman (HY), Ella Robinson (ER), Boyd Swinburn (BS), Stefanie Vandevijvere (SV), Karuthan Chinna (KC), Mohd Noor Ismail (MNI) \& Tilakavati Karupaiah (TK). TK, BS, BK, and SHN designed the study. GS and KC contributed to methodological development for this study. SHN, TK and MNI were involved in the industry stakeholder engagement. SHN and TK performed data acquisition and consolidated the evidence. GS, SHN, ER, BK, and HY standardised the assessment protocol. SHN, KC, and SV contributed statistical analysis. All authors contributed to data interpretation. SHN and TK drafted the manuscript. The authors read and approved the final manuscript.

\section{Funding}

This study was funded by the International Development Research Centre (IDRC), Canada (Grant No. 108176-001), a crown corporation under the Canada's government. In-kind contributions were supported by the School of Healthcare Sciences, Faculty of Health Sciences, Universiti Kebangsaan Malaysia (UKM), Malaysia; Centre for Research Management, Taylor's University, Malaysia; Early Start, School of Health and Society, Faculty of Social Sciences, University of Wollongong; the Australian Government for a Research Training Programme Scholarship awarded to SHN.

\section{Availability of data and materials}

The dataset will be available upon request to the corresponding author, excepting an individual company's confidential information bound by nondisclosure clauses.

\section{Ethics approval and consent to participate}

The study has received ethics approvals from the Research Ethics Committee of the National University of Malaysia (UKM PP1/111/8/JEP-2016-394); and the Social Science Human Research Ethics Committee of the University of Wollongong (HE16/297).

\section{Consent for publication}

Not applicable.

\section{Competing interests}

The authors declare that they have no conflicts of interest.

\section{Author details}

${ }^{1}$ Early Start, School of Health and Society, University of Wollongong, Northfields Avenue, Wollongong, NSW 2522, Australia. ${ }^{2}$ Global Obesity Centre (GLOBE), Deakin University, 221 Burwood Highway, Burwood, VIC 3125, Australia. ${ }^{3}$ School of Population Health, University of Auckland, 2 Morrin Road, Auckland 1072, New Zealand. ${ }^{4}$ School of Medicine, Faculty of Health and Medical Sciences, Taylor's University, 47500 Subang Jaya, Selangor, Malaysia. ${ }^{5}$ Faculty of Social Sciences and Leisure Management, Taylor's University, 47500 Subang Jaya, Selangor, Malaysia. ${ }^{6}$ Dietetics Programme, School of Healthcare Sciences, Faculty of Health Sciences, Universiti Kebangsaan Malaysia, 50300 Kuala Lumpur, Malaysia. ${ }^{7}$ School of Biosciences, Faculty of Health and Medical Sciences, Taylor's University, 47500 Subang Jaya, Selangor, Malaysia.

Received: 21 November 2019 Accepted: 23 March 2020 Published online: 17 April 2020

\section{References}

1. Ng M, Fleming T, Robinson M, Thomson B, Graetz N, Margono C, et al. Global, regional, and national prevalence of overweight and obesity in children and adults during 1980-2013: a systematic analysis for the global burden of disease study 2013. Lancet. 2014;384:766-81.

2. Institute for Public Health. National Health and Morbidity Survey. 2015: Noncommunicable diseases, Risk Factors \& Other Health Problems. Kuala Lumpur: National Institutes of Health, Ministry of Health; 2015.

3. World Health Organization (WHO). Noncommunicable diseases country profiles 2018. Geneva: WHO; 2018.

4. Institute for Health Metrics and Evaluation (IHME). GBD Compare Data Visualization [Malaysia]. 2018. http://vizhub.healthdata.org/gbd-compare. Accessed 9 Nov 2018. 
5. Baker P, Kay A, Walls H. Trade and investment liberalization and Asia's noncommunicable disease epidemic: a synthesis of data and existing literature. Glob Health. 2014;10:66.

6. Baker P, Friel S. Food systems transformations, ultra-processed food markets and the nutrition transition in Asia. Glob Health. 2016;12:88.

7. Monteiro CA, Moubarac JC, Cannon G, Ng SW, Popkin B. Ultra-processed products are becoming dominant in the global food system. Obes Rev. 2013;14(Suppl 2):21-8.

8. Vandevijvere $\mathrm{S}$, Jaacks LM, Monteiro CA, Moubarac JC, Girling-Butcher M, Lee AC, et al. Global trends in ultraprocessed food and drink product sales and their association with adult body mass index trajectories. Obes Rev. 2019;20(S2):10-19.

9. Department of Statistics Malaysia. Population distribution and basic demographic characteristic report 2010 (updated: 05/08/2011). 2015 https://www.dosm.gov.my/v1/index.php?r=column/ctheme\&menu_id= LOpheU43NWJwRWVSZkIWdzQ4TIhUUT09\&bul_id=MDMxdHZjWTk1 SjFzTzNkRXYzcVZjdz09\#. Accessed 11 Sept 2019.

10. Karupaiah T, Chuah KA, Chinna K, Pressman P, Clemens RA, Hates AW, et al. A cross-sectional study on the dietary pattern impact on cardiovascular disease biomarkers in Malaysia. Sci Rep. 2019;9:13666.

11. Buse K, Tanaka S, Hawkes S. Healthy people and healthy profits? Elaborating a conceptual framework for governing the commercial determinants of non-communicable diseases and identifying options for reducing risk exposure. Glob Health. 2017;13:34.

12. Kickbusch I. Addressing the commercial determinants is critical to emerging economies. Ciênc Saúde Colet. 2015;20(4):969.

13. World Health Organization (WHO). Global Action Plan for the Prevention and Control of Noncommunicable Diseases 2013-2020. Geneva: WHO; 2013.

14. World Health Organization (WHO). Report of the Commission on Ending Childhood Obesity: implementation plan. Seventieth World Health Assembly A70/31, 27 March 2017. 2017. http://apps.who.int/gb/ebwha/pdf_ files/WHA70/A70 31-en.pdf. Accessed 11 Nov 2019.

15. Economic Planning Unit (EPU). Eleventh Malaysia Plan 2016-2020: Anchoring Growth on People. Putrajaya: EPU, Prime Minister's Department: 2015.

16. National Coordinating Committee on Food and Nutrition (NCCFN). The National Plan of Action for Nutrition of Malaysia (NPANM III) 2016-2025. Putrajaya: NCCFN, MOH; 2016.

17. Ministry of Health (MOH). National Strategic Plan for Non-communicable Diseases (NSP-NCD) 2010-2014. Putrajaya: Non-Communicable Disease Section, Disease Control Division, MOH; 2010.

18. Ministry of Health (MOH). National Strategic Plan for Non-communicable Disease (NSP-NCD) 2016-2025. Putrajaya: Public Health Department, MOH; 2016.

19. Federation of Malaysian Manufacturers (FMM). Malaysian Food and Beverage Industry Commits to Combating Non-communicable Diseases (NCDs). 2015. http://www.fmm.org.my/Press_Releases-@-Malaysian_Food_ and_Beverage_Industry_Commits_To_Combating_Non-Communicable_ Diseases_(NCDs)_in_Partnership_with_the_Government.aspx\#. Accessed 8 Mar 2019.

20. Federation of Malaysian Manufacturers (FMM). FMM press release (7 November 2018): FMM MAFMAG Responses on 2019 Budget Announcement 2018. http://www.fmm.org.my/Press_Releases-@-FMM_ Press_Release-;_FMM_MAFMAG_Responses_on_2019_Budget_ Announcement.aspx\#. Accessed 8 Mar 2019.

21. Food Industry Asia (FIA). Malaysian Food and Beverage Industry's "Responsible Advertising to Children" Initiative (The Malaysia Pledge). 2013. https://ifballiance.org/uploads/regional/MALAYSIA_PLEDGE_FINAL_.pdf. Accessed 14 Sept 2017.

22. Sacks G, Swinburn B, Kraak V, Downs S, Walker C, Barquera S, et al. A proposed approach to monitor private sector policies and practices related to food environments, obesity and non-communicable disease prevention. Obes Rev. 2013;14(Suppl 1):38-48

23. Swinburn BA, Kraak VI, Allender S, Atkins VJ, Baker PI, Bogard JR, et al. The global Syndemic of obesity, Undernutrition, and climate change: the lancet commission report. Lancet. 2019:393:791-846.

24. World Health Organization (WHO). Time to Deliver: Report of the WHO Independent High-Level Commission on Noncommunicable Diseases. Geneva: WHO; 2018

25. Access to Nutrition Foundation (ATNF). Access to Nutrition Index - Global Index 2013. Netherlands: ATNF; 2013.
26. Access to Nutrition Foundation (ATNF). Access to Nutrition Index - Global Index 2018. Netherlands: ATNF; 2018.

27. Sacks G, Vanderlee V, Robinson E, Vandevijvere S, Cameron AJ, Mhurchu CN, et al. BIA-obesity (business impact assessment - obesity and populationlevel nutrition): a tool and process to assess food company policies and commitments related to obesity prevention and population nutrition at the national level. Obes Rev. 2019;20(S2):78-89.

28. Sacks G. Robinson E for INFORMAS. Inside our food and beverage manufacturers: assessment of company policies and commitments related to obesity prevention and nutrition, Australia 2018. Melbourne: Deakin University; 2018.

29. Sacks G. Robinson E for INFORMAS. Inside our quick service restaurants: assessment of company policies and commitments related to obesity prevention and nutrition, Australia 2018. Melbourne: Deakin University; 2018

30. Sacks G, Robinson E. Cameron a for INFORMAS. Inside our supermarkets: assessment of company policies and commitments related to obesity prevention and nutrition, Australia 2018. Melbourne: Deakin University; 2018.

31. Kasture A, Vandevijvere S, Robinson E, Sacks G, Swinburn B. Benchmarking the commitments related to population nutrition and obesity prevention of major food companies in New Zealand. Int J Public Health. 2019:64:1147-57.

32. Vanderlee L, Verger L, Sacks G, Robinson E, L'Abbé M. Food and beverage manufacturers in Canada: policies and commitments to improve the food environment. Toronto: The University of Toronto; 2019.

33. Kraak V, Patiño SRG, Renukuntla D, Kim E. Progress evaluation for transnational restaurant chains to reformulate products and standardize portions to meet healthy dietary guidelines and reduce obesity and noncommunicable disease risks, 2000-2018: a scoping and systematic review to inform policy. Int J Environ Res Public Health. 2019;16(2732):1-31.

34. Euromonitor International. Packaged Food: Brand Shares - Local Latest Owner. [Passport Statistics - Data Type: Retail Value RSP, Malaysia]. 2017. https://www.portal.euromonitor.com/portal/magazine/homemain. Accessed 7 Oct 2017

35. Euromonitor International. RTE Cereal, Instant Noodles, Cheese, Drinking Milk Products, Yoghurt and Sour Milk Products and Other Dairy: Brand Shares - Local Latest Owner. [Passport Statistics - Data Type: Retail Value RSP, Malaysia]. 2017. https://www.portal.euromonitor.com/portal/magazine/ homemain. Accessed 7 Oct 2017.

36. Euromonitor International. Carbonates, Concentrates, Juice, RTD Coffee, RTD Tea, Sports and Energy Drinks and Asian Speciality Drinks: Company Shares - National - Latest Owner. [Passport Statistics - Data Type: Retail Value RSP, Malaysia]. 2017. https://www.portal.euromonitor.com/portal/magazine/ homemain. Accessed 15 Aug 2017.

37. Euromonitor International. Fast Food and Pizza Consumer Foodservice: Brand Shares - Local - Latest Owner. [Passport Statistics - Data Type: Foodservice Value RSP, Malaysia].2017 https://www.portal.euromonitor.com/ portal/magazine/homemain. Accessed 30 July 2017.

38. Euromonitor International. Grocery Retailers: Company Shares - National Latest Owner. [Passport Statistics - Data Type: Retail Value RSP exclude Sales Tax, Malaysia]. 2017. https://www.portal.euromonitor.com/portal/magazine/ homemain. Accessed 15 Aug 2017.

39. Bursa Malaysia Berhad (Bursa Malaysia). List of Companies (Main Market) 2019. http://www.bursamalaysia.com/market/listed-companies/list-ofcompanies/main-market. Accessed 13 Oct 2019.

40. Vandevijvere S, Kasture A, Sacks G, Robinson E, Mackay S, Swinburn B. Committing to health: food company policies for healthier food environments. Company assessments and recommendations using the business impact assessment on obesity and population nutrition (BIAobesity) tool. New Zealand: The University of Auckland; 2018.

41. Baharad E, Ben-Yashar R, Nitzan S. Variable competence and collective performance: unanimity vs. simple majority rule. Tokyo: Hitotsubashi Institute for Advanced Study, Hitotsubashi University; 2018.

42. World Health Organization (WHO). WHO nutrient profile model for the Western Pacific Region 2016: a tool to protect children from food marketing. Manila: WHO, Regional Office for the Western Pacific; 2016.

43. World Health Organization (WHO). WHO Nutrient Profile Model for SouthEast Asia Region. New Delhi: WHO, Regional Office for South-East Asia; 2017.

44. Cetthakrikul N, Phulkerd S, Jaichuen N, Sacks G, Tangcharoensathien V. Assessment of the stated policies of prominent food companies related to obesity and non-communicable disease (NCD) prevention in Thailand. Glob Health. 2019:15:12 
45. Sacks G, Mialon M, Vandevijvere S, Trevena H, Snowdon W, Crino M, et al. Comparison of food industry policies and commitments on marketing to children and product (re)formulation in Australia, New Zealand and Fiji. Crit Public Health. 2015;25(3):299-319.

46. Bursa Malaysia Securities Berhad (Bursa Malaysia). Sustainability Reporting Guide. 2nd ed. Kuala Lumpur: Bursa Malaysia; 2018.

47. Swinburn B, Kraak V, Rutter H, Vandevijvere S, Lobstein T, Sacks G, et al. Strengthening of accountability systems to create healthy food environments and reduce global obesity. Lancet. 2015;385(9986):2534-45.

48. Mialon M, Swinburn B, Sacks G. A proposed approach to systematically identify and monitor the corporate political activity of the food industry with respect to public health using publicly available information. Obes Rev. 2015;16(7):519-30.

49. Collin J, Hill SE, Eltanani MK, Plotnikova E, Ralston R, Smith KE. Can public health reconcile profits and pandemics? An analysis of attitudes to commercial sector engagement in health policy and research. PLoS One. 2017;12(9):e0182612.

50. Kraak VI, Harrigan PB, Lawrence M, Harrison PJ, Jackson MA, Swinburn B. Balancing the benefits and risks of public-private partnerships to address the global double burden of malnutrition. Public Health Nutr. 2011;15(3): 503-17.

51. Moodie R, Stuckler D, Monteiro C, Sheron N, Neal B, Thamarangsi T, et al. Profits and pandemics: prevention of harmful effects of tobacco, alcohol, and ultra-processed food and drink industries. Lancet. 2013;381:670-9.

52. Draper AK, Adamson AJ, Clegg S, Malam S, Rigg M, Duncan S. Front-of-pack nutrition labelling: are multiple formats a problem for consumers? Eur J Pub Health. 2011;23(3):517-21.

53. Kelly $B$, Jewell J. Health evidence network (HEN) synthesis report 61: what is the evidence on the policy specifications, development processes and effectiveness of existing front-of-pack food labelling policies in the WHO European Region? WHO regional Office for Europe: Copenhagen; 2018.

54. Federation of Malaysian Consumers Associations (FOMCA). Malaysian Consumers Wishlist for the $13^{\text {th }}$ General Election. Petaling Jaya: FOMCA; 2012.

55. Nutrition Division. Nutrient criteria Healthier Choice Logo (HCL) Malaysia. 2017. http://myhcl.moh.gov.my/assets/doc/nutrient_criteria.pdf. Accessed 15 Aug 2019.

56. Ministry of Health of Brazil. Dietary guidelines for the Brazilian population. 2nd ed; 2014. https://www.foodpolitics.com/wp-content/uploads/BrazilianDietary-Guidelines-2014.pdf. Accessed 20 Sept 2019.

57. WHO Western Pacific Region. Biregional workshop on restricting the Marketing of Foods and non-alcoholic Beverages to children in the Western Pacific and South-East Asia. 2016. https://iris.wpro.who.int/bitstream/ handle/10665.1/13373/RS_2015_GE_61_MYS_eng.pdf. Accessed 16 Sept 2019.

58. United Nations Committee on the Rights of the Child (UNCRC). General comment no. 15 (2013) on the right of the child to the enjoyment of the highest attainable standard of health (art. 24), 17 April 2013, CRC/C/GC/15. 2013. https://www.refworld.org/docid/51 ef9e134.html. Accessed 7 Mar 2019

59. Ng SH, Swinburn B, Kelly B, Vandevijvere S, Yeatman H, Ismail MN, et al. Extent of implementation of food environment policies by the Malaysian government: gaps and priority recommendations. Public Health Nutr. 2018; 21(18):3395-406

60. Wootan MG, Almy J, Ugalde M, Kaminski M. How do nutrition guidelines compare for industry to market food and beverage products to children? World Health Organization nutrient profile standards versus the US Children's food and beverage advertising initiative. Child Obes. 2019;15(3): 194-9.

61. Sacks G, Rayner M, Stockley L, Scarborough P, Snowdon W, Swinburn B. Applications of nutrient profiling: potential role in diet-related chronic disease prevention and the feasibility of a core nutrient-profiling system. Eur J Clin Nutr. 2011;65:298-306.

\section{Publisher's Note}

Springer Nature remains neutral with regard to jurisdictional claims in published maps and institutional affiliations.

\section{Ready to submit your research? Choose BMC and benefit from:}

- fast, convenient online submission

- thorough peer review by experienced researchers in your field

- rapid publication on acceptance

- support for research data, including large and complex data types

- gold Open Access which fosters wider collaboration and increased citations

- maximum visibility for your research: over $100 \mathrm{M}$ website views per year

At BMC, research is always in progress.

Learn more biomedcentral.com/submissions 